Atmos. Chem. Phys., 13, 1129-1139, 2013

www.atmos-chem-phys.net/13/1129/2013/

doi:10.5194/acp-13-1129-2013

(c) Author(s) 2013. CC Attribution 3.0 License.

\title{
Peroxyacetyl nitrate (PAN) and peroxyacetic acid (PAA) measurements by iodide chemical ionisation mass spectrometry: first analysis of results in the boreal forest and implications for the measurement of PAN fluxes
}

\author{
G. J. Phillips ${ }^{1}$, N. Pouvesle ${ }^{1, *}$, J. Thieser ${ }^{1}$, G. Schuster ${ }^{1}$, R. Axinte ${ }^{1}$, H. Fischer ${ }^{1}$, J. Williams ${ }^{1}$, J. Lelieveld ${ }^{1}$, and \\ J. N. Crowley ${ }^{1}$ \\ ${ }^{1}$ Department of Atmospheric Chemistry, Max Planck Institute for Chemistry, Hahn-Meitner Weg 1, 55128 Mainz, Germany \\ * now at: ET Energie Technologie GmBH, Eugen-Sänger-Ring 4, 85649 Brunnthal, Germany
}

Correspondence to: G. J. Phillips (gavin.phillips@mpic.de)

Received: 20 July 2012 - Published in Atmos. Chem. Phys. Discuss.: 13 August 2012

Revised: 21 January 2013 - Accepted: 21 January 2013 - Published: 1 February 2013

\begin{abstract}
We describe measurements of peroxyacetyl nitrate $\left(\mathrm{CH}_{3} \mathrm{C}(\mathrm{O}) \mathrm{O}_{2} \mathrm{NO}_{2}\right.$, PAN $)$ and peroxyacetic acid $\left(\mathrm{CH}_{3} \mathrm{C}(\mathrm{O}) \mathrm{OOH}, \mathrm{PAA}\right)$ in the Boreal forest using iodide chemical ionization mass spectrometry (ICIMS). The measurements were made during the Hyytiälä United Measurement of Photochemistry and Particles - Comprehensive Organic Particle and Environmental Chemistry (HUMPPACOPEC-2010) measurement intensive. Mixing ratios of PAN and PAA were determined by measuring the acetate ion signal $\left(\mathrm{CH}_{3} \mathrm{C}(\mathrm{O}) \mathrm{O}^{-}, m / z=59\right)$ resulting from reaction of $\mathrm{CH}_{3} \mathrm{C}(\mathrm{O}) \mathrm{O}_{2}$ (from the thermal dissociation of $\mathrm{PAN}$ ) or $\mathrm{CH}_{3} \mathrm{C}(\mathrm{O}) \mathrm{OOH}$ with iodide ions using alternatively heated and ambient temperature inlet lines. During some periods of high temperature $\left(\sim 30^{\circ} \mathrm{C}\right)$ and low $\mathrm{NO}_{\mathrm{x}}(<1 \mathrm{ppbv})$, PAA mixing ratios were similar to, or exceeded those of PAN and thus contributed a significant fraction of the total acetate signal. PAA is thus a potential interference for ICIMS measurements of PAN, and especially eddy covariance flux measurements in environments where the PAA flux is likely to be a significant proportion of the (short timescale) acetate ion variability. Within the range of mixing ratios of $\mathrm{NO}_{\mathrm{x}}$ measured during HUMPPA-COPEC, the modelled ratio of PAAto-PAN was found to be sensitive to temperature (through the thermal decomposition rate of PAN) and the $\mathrm{HO}_{2}$ mixing ratio, thus providing some constraint to estimates of photochemical activity and oxidation rates in the Boreal environment.
\end{abstract}

\section{Introduction}

Peroxyacyl nitrates $\left(\mathrm{RC}(\mathrm{O}) \mathrm{OONO}_{2}\right.$ or PANs) are an important class of atmospheric trace species formed via the reaction of $\mathrm{NO}_{2}$ with peroxyacyl radicals $\left(\mathrm{RC}(\mathrm{O}) \mathrm{O}_{2}\right)$, themselves formed from the oxidation and photolysis of volatile organic trace gases (VOCs). PANs have been widely studied owing to their properties as phytotoxic agents and lachrymatory components of air pollution (Stephens et al., 1961). In polluted regions, where ozone production is VOC limited, PANs sequester significant amounts of $\mathrm{NO}_{\mathrm{x}}$ thus increasing the chain length of the $\mathrm{HO}_{\mathrm{x}}$ cycle. A further important property of PANs is their thermal instability, leading to short atmospheric lifetimes at high temperatures $(1.5 \mathrm{~h}$ at $293 \mathrm{~K})$ and moderate to long lifetimes at lower temperatures $(50 \mathrm{~h}$ at $273 \mathrm{~K})$. This instability allows for the re-release of $\mathrm{NO}_{\mathrm{x}}$ and $\mathrm{RC}(\mathrm{O}) \mathrm{O}_{2}$ far from their source regions making PANs potentially important components of nitrogen deposited in sensitive rural ecosystems (Sparks et al., 2003). The most abundant and most studied of the PANs is peroxyacetyl nitrate (PAN, $\mathrm{CH}_{3} \mathrm{C}(\mathrm{O}) \mathrm{O}_{2} \mathrm{NO}_{2}$ ) (e.g. Singh and Hanst, 1981; Singh and Salas, 1983; Singh et al., 1992; Roberts et al., 1998, 2003, 2007; LaFranchi et al., 2009; Fischer et al., 2011). PAN is formed in Reaction (R1) between $\mathrm{NO}_{2}$ and the peroxyacetyl radical $\mathrm{CH}_{3} \mathrm{C}(\mathrm{O}) \mathrm{O}_{2}$, an intermediate in the oxidation of anthropogenic (e.g. propane) and biogenic VOCs (e.g. isoprene and $\alpha$-pinene, LaFranchi et al., 2009; Atkinson and

Published by Copernicus Publications on behalf of the European Geosciences Union. 
Arey, 2003; Peeters et al., 2001; Fantechi et al., 2002) as illustrated in Fig. 1.

$$
\begin{aligned}
& \mathrm{CH}_{3} \mathrm{C}(\mathrm{O}) \mathrm{O}_{2}+\mathrm{NO}_{2}+\mathrm{M} \rightarrow \mathrm{CH}_{3} \mathrm{C}(\mathrm{O}) \mathrm{O}_{2} \mathrm{NO}_{2}+\mathrm{M} \\
& \mathrm{CH}_{3} \mathrm{C}(\mathrm{O}) \mathrm{O}_{2} \mathrm{NO}_{2}+\mathrm{M} \rightarrow \mathrm{CH}_{3} \mathrm{C}(\mathrm{O}) \mathrm{O}_{2}+\mathrm{NO}_{2}+\mathrm{M} \\
& \mathrm{CH}_{3} \mathrm{C}(\mathrm{O}) \mathrm{O}_{2}+\mathrm{NO} \rightarrow \mathrm{CH}_{3}+\mathrm{CO}_{2}+\mathrm{NO}_{2}
\end{aligned}
$$

PAN is long-lived with respect to reaction with $\mathrm{OH}(\sim 1 \mathrm{yr}$ at $[\mathrm{OH}]=1 \times 10^{6}$ molecule $\mathrm{cm}^{-3}$ ) or photolysis (30 days) and its lifetime in the boundary layer (Talukdar et al., 1995) is controlled by thermal decomposition (in the presence of $\mathrm{CH}_{3} \mathrm{C}(\mathrm{O}) \mathrm{O}_{2}$ scavengers such as $\mathrm{NO}$ in Reaction R3) and by transport and deposition. The peroxyacetyl radical is permanently removed in reaction with $\mathrm{NO}$ whereby the carbonyl functionality ends up as $\mathrm{CO}_{2}$ via decomposition of the intermediate $\mathrm{CH}_{3} \mathrm{CO}_{2}$ carboxyl radical (not shown).

Figure 1 also indicates that peroxyacetic acid, PAA is formed in the competitive Reaction (R3a) of the $\mathrm{CH}_{3} \mathrm{C}(\mathrm{O}) \mathrm{O}_{2}$ radicals with $\mathrm{HO}_{2}$. The formation of PAA in Reaction (R4) represents just one channel of this reaction with (R4b) and (R4c) also contributing significantly (Dillon and Crowley, 2008; Taraborrelli et al., 2012):

$$
\begin{aligned}
\mathrm{CH}_{3} \mathrm{C}(\mathrm{O}) \mathrm{O}_{2}+\mathrm{HO}_{2} & \rightarrow \mathrm{CH}_{3} \mathrm{C}(\mathrm{O}) \mathrm{OOH}+\mathrm{O}_{2} \\
& \rightarrow \mathrm{CH}_{3} \mathrm{C}(\mathrm{O}) \mathrm{OH}+\mathrm{O}_{3} \\
& \rightarrow \mathrm{OH}+\mathrm{CH}_{3}+\mathrm{O}_{2}+\mathrm{CO}_{2}
\end{aligned}
$$

Under most atmospheric conditions, the rate coefficients for reaction of $\mathrm{CH}_{3} \mathrm{C}(\mathrm{O}) \mathrm{O}_{2}$ with $\mathrm{NO}_{2}$ and $\mathrm{HO}_{2}$ are similar $\left(k_{1}\right.$ and $k_{4}$ at $298 \mathrm{~K}$ and 1 bar pressure are $9.3 \times 10^{-12}$ and $1.4 \times 10^{-11} \mathrm{~cm}^{3}$ molecule $\mathrm{e}^{-1} \mathrm{~s}^{-1}$, respectively) and the relative flux of $\mathrm{CH}_{3} \mathrm{C}(\mathrm{O}) \mathrm{O}_{2}$ radicals into the PAN and PAA forming channels will depend on the relative abundance of $\mathrm{NO}_{2}$ and $\mathrm{HO}_{2}$, which, apart from extremely clean low- $\mathrm{NO}_{\mathrm{x}}$ environments (when $\left[\mathrm{HO}_{2}\right]>\left[\mathrm{NO}_{2}\right]$ ) will generally favour PAN. However, as stated above, in the summertime boundary layer, PAN is short lived and will readily decompose to $\mathrm{CH}_{3} \mathrm{C}(\mathrm{O}) \mathrm{O}_{2}$, implying that the formation of the thermally stable peroxyacid will be a significant $\mathrm{CH}_{3} \mathrm{C}(\mathrm{O}) \mathrm{O}_{2}$ sink in warm conditions with reasonably low $\mathrm{NO}_{\mathrm{x}}$ levels, e.g. as encountered during HUMPPA-COPEX 2010 (see later). The lifetime of PAA with respect to photolysis is several weeks and (in the absence of a measurement of the rate coefficient) estimates of its lifetime due to reaction with $\mathrm{OH}$ are between 2 and 12 days (Orlando and Tyndall, 2003) reforming $\mathrm{CH}_{3} \mathrm{C}(\mathrm{O}) \mathrm{O}_{2}$ (Reaction R5).

$$
\mathrm{CH}_{3} \mathrm{C}(\mathrm{O}) \mathrm{OOH}+\mathrm{OH} \rightarrow \mathrm{CH}_{3} \mathrm{C}(\mathrm{O}) \mathrm{O}_{2}+\mathrm{H}_{2} \mathrm{O}
$$

With a moderate solubility (measurements vary between 670 and $840 \mathrm{M} \mathrm{atm}^{-1}$ at $298 \mathrm{~K}$, Sander, 1999) the boundary layer lifetime of PAA will also be partially determined by deposition, especially in forested regions. Similar to the role of NO

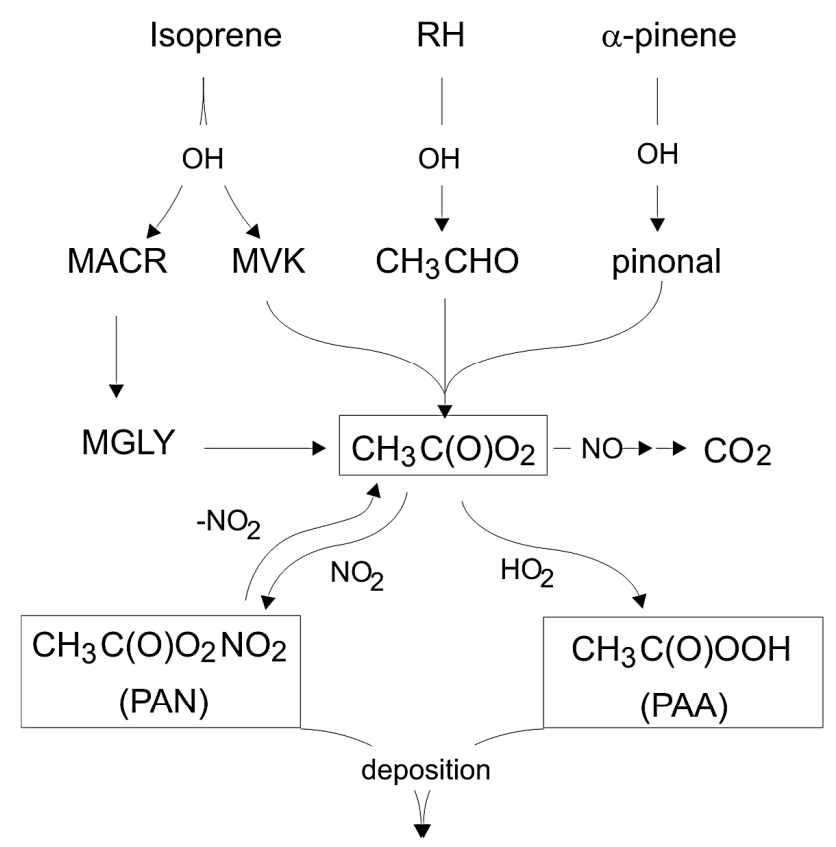

Fig. 1. Exemplary reaction scheme ilustrating the production of the peroxyacetyl radical (PA) from a number of VOC oxidation pathways.

in Reaction (R3), PAA formation can thus be considered an indirect sink for PAN as it drains $\mathrm{CH}_{3} \mathrm{C}(\mathrm{O}) \mathrm{O}_{2}$ radicals from the equilibrium between Reactions (R1) and (R2).

In the absence of a direct, biogenic emission, the PAA mixing ratio can be an important indicator of photochemical activity and (at low $\mathrm{NO}_{\mathrm{x}}$ ) acts as a sink for both $\mathrm{CH}_{3} \mathrm{C}(\mathrm{O}) \mathrm{O}_{2}$ and $\mathrm{HO}_{2}$. Despite this, field measurements of PAA (sometimes measured alongside other organic peroxides with HPLC) are few and far between (Fels and Junkermann, 1994; Zhang et al., 2010; He et al., 2010), though chemical ionisation mass spectrometry using $\mathrm{CF}_{3} \mathrm{O}^{-}$ions appears to be a promising new technique (Crounse et al., 2006). Fels and Junkermann (1994) reported measurements of a number of speciated organic peroxides by cryogenic trapping followed by HPLC. Quantitative results were not reported as the measurement suffered from HPLC column losses. Crounse et al. (2006) reported a new technique for the detection of PAA using CIMS, utilising the reagent ion $\mathrm{CF}_{3} \mathrm{O}^{-}$. The authors report a PAA measurement comparison between the CIMS technique and a HPLC method during the INTEX-NA campaign onboard the NASA DC-8 research aircraft: PAA concentrations of between approximately 100 and 800 pptv were reported. He et al. (2010) measured a number of peroxides including PAA using a HPLC technique, before and during the 2008 Olympic Games in Beijing: Concentrations of up to $140 \mathrm{pptv}$ with mean concentrations of approximately 25 pptv in mean $\mathrm{NO}_{\mathrm{x}}$ conditions of between 20 and 30 ppbv during July 2008. Zhang et al. (2010) also used HPLC to measure ambient PAA and report time series 
measured at a number of locations in China. PAA mixing ratios of 10 to $1000 \mathrm{pptv}$ were reported: an analysis using Principle Factor Analysis found that high concentrations occurred during hot periods and the lowest concentrations of PAA occurred during periods of high $\mathrm{NO}_{\mathrm{x}}$. It may also be possible to measure PAA in addition to PAN using protontransfer selective ion flow tube mass spectrometry (SIFTMS) as reported by Hastie et al. (2010).

A recent development in PAN measurements has been the use of iodide ion mass spectrometry (Slusher et al., 2004) which uses the thermal instability of PAN and the reaction of $\mathrm{CH}_{3} \mathrm{C}(\mathrm{O}) \mathrm{O}_{2}$ with I- to generate the acetate ion, $\mathrm{CH}_{3} \mathrm{CO}_{2}^{-}$, which is detected at $m / z=59$ :

$$
\mathrm{CH}_{3} \mathrm{C}(\mathrm{O}) \mathrm{O}_{2}+\mathrm{I}^{-} \rightarrow \mathrm{CH}_{3} \mathrm{CO}_{2}^{-}+\mathrm{IO}
$$

This technique has been used to make measurements with high sensitivity and at high time resolution (Wolfe et al., 2007; LaFranchi et al., 2010; Roiger et al., 2011) e.g. for use in eddy correlation studies of PAN deposition (Turnipseed et al., 2006; Wolfe et al., 2009). Whilst calibration and airmatrix artefacts associated with the measurement of PAN (and other PANs) with this technique have received some attention (Zheng et al., 2011; Mielke and Osthoff, 2012) here we focus on the discovery that PAA is also converted to the acetate ion via reaction with $\mathrm{I}^{-}$and, when attempting to measure PAN, represents a non-trivial source of acetate ion signal both in terms of magnitude and variability.

A number of studies comparing ICIMS to other methods of PAN detection, i.e. GC and thermal dissociationlaser-induced fluorescence (TD-LIF), have been published (Wooldridge et al., 2010; Slusher et al., 2004; Zheng et al., 2011). Comparisons, in the main, show reasonably good agreement between ICIMS and other techniques and any systematic differences were not ascribed to the possible interference of PAA. In particular, the ICIMS operating conditions used and described by Zheng et al. (2011) do not appear to be sensitive to PAA. However, in his review of this paper, J. Thornton presents a reanalysis of the data presented in Wolfe et al. (2009) where he examines the CIMS background signal obtained via addition of NO to the ambient sample (http://www.atmos-chem-phys-discuss.net/12/ C7744/2012/acpd-12-C7744-2012-supplement.pdf). As this method of background determination does not remove PAA, any response from ambient PAA should appear in this background data. There is reasonably good agreement $\left(r^{2}=0.71\right)$ between the ICIMS background and unpublished PAA determined via the Caltech $\mathrm{CF}_{3} \mathrm{O}^{-}$CIMS (Crounse et al., 2006) which suggests that the ICIMS was sensitive to PAA albeit with a low sensitivity of approximately $0.4 \mathrm{~Hz} \mathrm{pptv}^{-1}$.

We present a dataset of quasi-simultaneous PAN and PAA measurements made during the HUMPPA-COPEC campaign and also note the potential pitfalls when attempting measurements of PAN fluxes in similar environments. We also emphasise the positive aspects of the accidental discovery during HUMPPA-COPEC-2010 that PAA can be sen- sitively and rapidly detected using the ICIMS method, and in a preliminary analysis, indicate how PAA and PAN measurements together can give new insight into photo-oxidation processes in the low and high $\mathrm{NO}_{\mathrm{x}}$ regimes.

\section{Methods}

\subsection{HUMPPA-COPEC site and ancillary measurements}

The measurements presented in this paper were made as part of the summertime boreal forest measurement intensive (HUMPPA-COPEC-2010). The field site and the majority of variable measured during the intensive are described in detail by Williams et al. (2011). The HUMPPA-COPEC measurement tower, operated by the University of Helsinki, was located at the SMEAR II-Hyytiälä station within the boreal forest (Latitude $61^{\circ} 51^{\prime} \mathrm{N}$; Longitude $24^{\circ} 17^{\prime} \mathrm{E}$ ). The forest surrounding the site was dominated by a mixture of coniferous forest (Scots pine [Pinus silvestris L.] and Norway spruce [Picea abies L.]) and mixed forest (conifers and Silver birch [Betula pendula Roth]). The measurement tower was situated on the edge of a small clearing, approximately $20 \mathrm{~m}$ in diameter, within the surrounding forest.

\subsection{Instrumentation}

\subsubsection{PAN and PAA via ICIMS}

The CIMS instrument was constructed by THS Instruments, Georgia, USA and is based on the thermal dissociationCIMS instrument described by (Slusher et al. (2004) and Zheng et al. (2011) with minor differences. The instrument includes four components: thermal dissociation (TD), ionmolecule reactor (IMR), collisional de-clustering (CDC), and mass selection (QMA). The thermal dissociation region consists of a $15 \mathrm{~cm}$ section of $3 / 8^{\prime \prime}$ outside diameter Teflon tube (PFA) heated to a temperature of $423 \mathrm{~K}$ measured on the external surface of the tube by a thermocouple. Laboratory characterization of the inlet showed this temperature to give the best yield of $\mathrm{CH}_{3} \mathrm{CO}_{2}^{-}$ions for a constant flow of PAN (Fig. 2a). The temperature of the gas flowing through the inlet was not determined.

The heated PFA tube is attached in front of an FEP-coated stainless steel orifice leading to the IMR resulting in an unheated region of $10 \mathrm{~mm}$ between the orifice and heated region. The orifice size is adjustable and a pressure of 21 Torr is maintained within the IMR independent of the external pressure. A flow of $1 \mathrm{~L}$ (STD) $\min ^{-1}$ of $\mathrm{N}_{2}$ and $\mathrm{CH}_{3} \mathrm{I}$ is added to the IMR via a Po-210 radioactive source generating iodide ions. The sample passes through a second orifice of $0.8 \mathrm{~mm}$ to the collisional dissociation chamber (CDC), held at a pressure of $5 \times 10^{-2}$ Torr and voltage biased relative to the IMR resulting in a ratio of $\mathrm{I}^{-} / \mathrm{I}\left(\mathrm{H}_{2} \mathrm{O}\right)^{-} \mathrm{Hz} / \mathrm{Hz}$ of 3.1 at $80 \% \mathrm{RH}$ and $22^{\circ} \mathrm{C}$, before finally entering an octopole ion guide and the quadrupole mass analyser (QMA). 


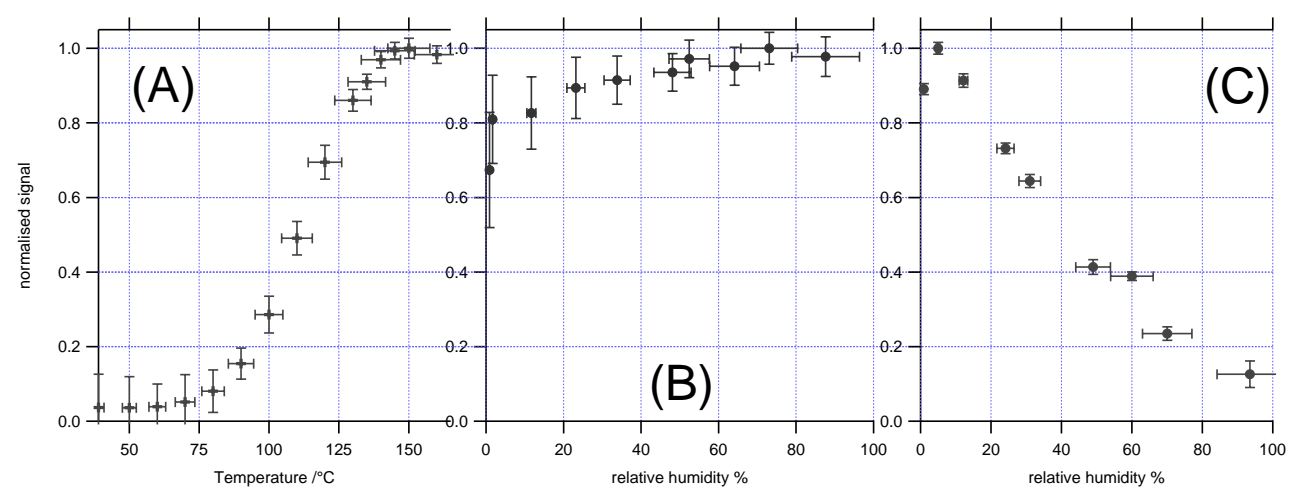

Fig. 2. (A) The dependence of the MPI ICIMS detection of PAN at $m / z=59$ as function of thermal dissociation temperature. The uncertainty in the PAN signal is $1 \sigma$ and is a function of both the total signal and the subtraction of the background from the PAN source. The uncertainty in the temperature is given as $5 \%$. (B) The normalised response of PAN vesus the relative humidity of the air sample. (C) The normalised response to PAA versus the relative humidity of the air sample. Uncertainty of the signal at $m / z=59$ is shown as $1 \sigma$ and the uncertainty in relative humidity is $10 \%$.

The background is determined by diverting the inlet flow through a $30 \mathrm{~cm}$ section of metal tubing heated to $473 \mathrm{~K}$ and filled with steel wool to destroy any analyte (both PAN and PAA) in the flow. The instrument was calibrated on-line using a photochemical PAN source similar to that described by Warneck and Zerbach (1992) which was continuously operated and switched into the zero air flow during calibration periods every hour. The effect of artefacts resulting from the photolysis of acetone in the source was accounted for by measuring the response to the source with an ambient temperature inlet and subtracting any subsequent signal. The cold-inlet background was found to be of the order of $10 \%$ of the total signal, likely due to PAA. The photochemical PAN source was calibrated prior to and during the campaign using thermal-dissociation cavity ring-down spectroscopy (TDCRDS) similar to described in Furgeson et al. (2011). The output of the PAN source was approximately 150 pptv corresponding to a sensitivity of $17 \mathrm{~Hz} \mathrm{pptv}^{-1}$ at $1 \times 10^{6} \mathrm{~Hz} \mathrm{I}^{-}$.

The sample inlet was situated on the main HUMPPACOPEC instrument tower, a height of $20 \mathrm{~m}$ above the ground at approximately the same height as the surrounding tree canopy. The sampling line consisted of $\sim 30 \mathrm{~m}$ of $1 / 4^{\prime \prime}$ OD, PFA tubing which was maintained at about $30^{\circ} \mathrm{C}$. The sample was drawn down the tubing at a flowrate of $6 \mathrm{~L}(\mathrm{STD}) \mathrm{min}^{-1}$ resulting in a residence time of approximately $1 \mathrm{~s}$. The sample line was not characterized for loss of PAN or PAA. A sub-sample of $2 \mathrm{~L}(\mathrm{STD}) \mathrm{min}^{-1}$ was drawn from the main inlet to the CIMS, a distance of about $3 \mathrm{~m}$, of which $1 \mathrm{~L}$ (STD) $\min ^{-1}$ was drawn into the CIMS itself.

During the campaign setup phase the instrument was sporadically operated without heating the thermal dissociation region (precluding detection of PAN) and an ambient signal at $m / z=59$ was recorded which revealed high temporal variability. We determined that this signal was likely due to the presence of PAA and the instrument was subsequently operated with an alternating heated and ambient temperature cycle for the thermal dissociation region.

As we had not anticipated detection of PAA, the ICIMS sensitivity and its dependence of humidity was determined post-campaign. A PAA standard was produced by sampling the dynamically diluted head space of a sample of $40 \%$ PAA in acetic acid simultaneously with the iodide CIMS and an ROOH instrument, described below. The small interference from acetic acid in the standard was removed by using a pure acetic acid standard, recording mass scans and calculating the signal ratio of $\mathrm{m} / z 187$ : $59\left(\mathrm{CH}_{3} \mathrm{C}(\mathrm{O}) \mathrm{OHI}^{-}: \mathrm{CH}_{3} \mathrm{C}(\mathrm{O}) \mathrm{O}^{-}\right)$. A multipoint calibration was performed and the CIMS sensitivity to PAA was determined to be $5.7 \mathrm{Hzpptv}^{-1}$ at $290 \mathrm{~K}$ and $\mathrm{RH}$ of $1 \%$ at 760 Torr and $26^{\circ} \mathrm{C}$. The detection sensitivity was found to be non-monotonically dependent on the absolute humidity (Fig. 2c) and the raw data were corrected for the relevant range of humidity measured during HUMPPA-COPEC 2010. The dependence of the PAN detection sensitivity on humidity was also determined and found to be relatively weak for the range of humidity encountered during the campaign (Fig. 2b). The weak, positive dependence on humidity at $\mathrm{RH}$ values between $\sim 10$ and $\sim 60 \%$ is very similar to that observed previously for PAN detection via ICIMS (Slusher et al., 2004; Zheng et al., 2011). The detection of PAA at $m / z=59$ presumably occurs via abstraction at the weak $\mathrm{O}-\mathrm{OH}$ bond of the peroxy acid, with reaction enthalpy of $-78 \mathrm{~kJ} \mathrm{~mol}^{-1}$ :

$\mathrm{CH}_{3} \mathrm{C}(\mathrm{O}) \mathrm{OOH}+\mathrm{I}^{-} \rightarrow \mathrm{CH}_{3} \mathrm{CO}_{2}^{-}+\mathrm{HOI}$

with the resulting acetate ion being detected (Furgeson et al., 2011; Mielke and Osthoff, 2012). The fact that the signal is reduced at very low $\mathrm{RH}$ suggests that the dominant ionizing ion is in fact $\mathrm{I}^{-}\left(\mathrm{H}_{2} \mathrm{O}\right)_{n}$ as for PAN.

Reasons for the complex RH dependence of the $m / z$ signal due to PAA are not completely clear; however some initial 
investigations have been completed. Tests with the calibration standard indicate that at high humidities, water-acetate clusters are produced in the $\operatorname{IMR}\left[\left(\mathrm{H}_{2} \mathrm{O}\right)_{n} \mathrm{CH}_{3} \mathrm{C}(\mathrm{O}) \mathrm{O}^{-}\right.$, where $n=0,2$ and 1 in order of decreasing abundance]. When sufficient potential is applied in the CDC, these ions are likely to be detected at $n=0$, i.e $m / z=59$. However, at lower declustering energies (and sufficient RH) PAA is also detected at $m / z=203$ and 221 corresponding to the ions $\mathrm{CH}_{3} \mathrm{C}(\mathrm{O}) \mathrm{OOHI}^{-}$and $\left(\mathrm{H}_{2} \mathrm{O}\right) \mathrm{CH}_{3} \mathrm{C}(\mathrm{O}) \mathrm{OOHI}^{-}$. These signals dramatically decrease and in the case of $\mathrm{m} / z=221$ disappear when the instrument is operated using the normal declustering potentials. It is therefore possible that the negative humidity dependence at $\mathrm{RH}>2 \%$ is due to the increased number of $\left(\mathrm{H}_{2} \mathrm{O}\right)_{n} \mathrm{CH}_{3} \mathrm{C}(\mathrm{O}) \mathrm{OOHI}^{-}$formed at high humidity which are subsequently removed in the declustering region and fail to form the acetate ion and are thus not detected at $m / z=59$. Alternatively, further reactions in the IMR of $\left(\mathrm{H}_{2} \mathrm{O}\right)_{n} \mathrm{CH}_{3} \mathrm{C}(\mathrm{O}) \mathrm{OOHI}^{-}$with $\mathrm{H}_{2} \mathrm{O}$ which do not lead (after declustering) to $\mathrm{CH}_{3} \mathrm{C}(\mathrm{O}) \mathrm{O}^{-}$would also lead to a complex dependence on $\mathrm{RH}$ as observed.

The PAA sensitivity at $m / z=59$ is about 2.5 times less ( 7 $\mathrm{Hz} \mathrm{pptv}^{-1}$ ) than that for PAN at low humidity. Although this value was obtained under the same mass spectrometer operating conditions, we recognise that post-campaign calibration is non-ideal and the error associated with the PAA measurement is adjusted accordingly. As loss of the $\mathrm{CH}_{3} \mathrm{C}(\mathrm{O}) \mathrm{O}_{2}$ radical in passing through the TD region and into the IMR is expected to be significant compared to loss of PAA, the relative rate constant $k_{6} / k_{7}$ is expected to be greater than 2.5.

Although not calibrated, several other mass-to-charge ratios $(m / z=73,85,87)$ were monitored when the inlet was not heated, and these are assigned to further peracids i.e. permethacrylic acid (PMA), perpropanoic acid and perbutanoic acid formed in competition to the APN at higher $\mathrm{NO}_{\mathrm{x}}$ levels and lower temperatures. Raw count rates for the unheated period reached a maximum of $50 \%$ of the gross heated inlet signal for $m / z=85$ and 87 , and $30 \%$ of the gross heated inlet signal for $m / z=73$. There is a potential inferring ion, $\mathrm{CF}_{3} \mathrm{O}^{-}$, appearing at $m / z=85$ arising from the outgassing of new heated Teflon tubing which can compromise measurements of MPAN (Zheng et al., 2011).

The signal due to the sum of PAN + PAA (hot inlet) was monitored continuously and the inlet was cooled to ambient temperature for $10 \mathrm{~min}$ once an hour to determine the concentration of PAA. The signal due to PAA was linearly interpolated and subtracted from the PAA + PAN signal to give the signal due to PAN. This approach is obviously not ideal and it is not likely that a linear interpolation was appropriate throughout the time series. Figure 3 shows an expanded section of the time series of PAN, PAA, and organic peroxides to illustrate in more detail the variation of the PAA signal with reference to the organic peroxides. It is clear that there are periods when the organic peroxide signal deviates from an hourly linear change: after 08:00 on 26 July there is an approximate 100 pptv non-linear excursion in organic perox-

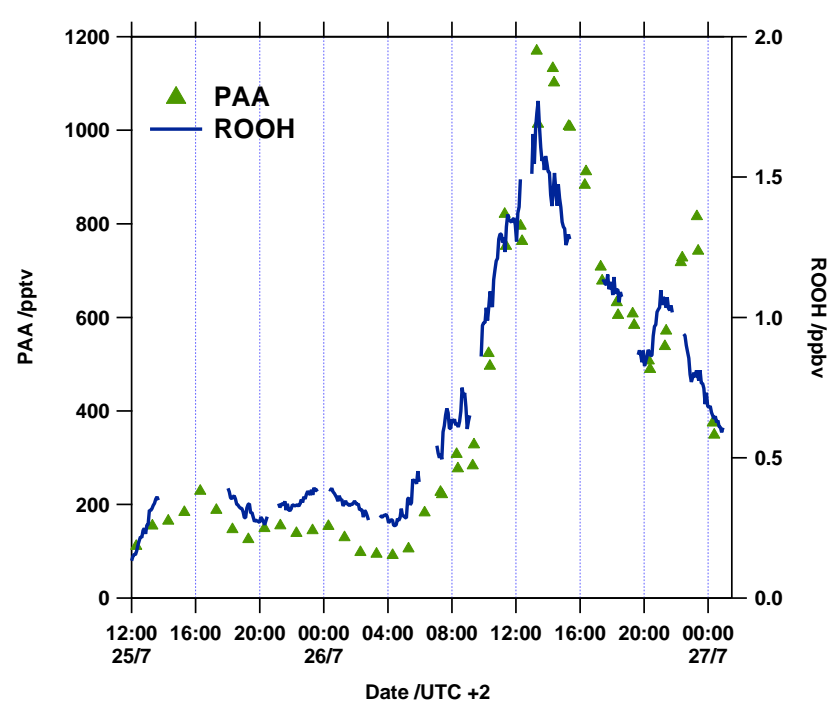

Fig. 3. Time series of total organic peroxides (ROOH) and PAA between midday 25 July and midnight 26 July 2010.

ides between PAA data points. Assuming that half of the peroxide variation was due to PAA and the relative PAN/PAA sensitivity was 2.5 , then the error on the PAN determination would be 10 pptv or in this case about $4 \%$.

In addition to "interference" at $m / z=59$ due to the direct sensitivity to PAA described here, detection of PANs using TD-ICIMS suffers from known matrix effects via reactions of $\mathrm{NO}_{\mathrm{x}}$ and organic acids. Mielke and Osthoff (2012) have shown that high $\mathrm{NO}_{\mathrm{x}}$ conditions can result in a significant negative bias on the detection of PANs, particularly the higher PANs (e.g. MPAN, APAN) via the reaction of NO or $\mathrm{NO}_{2}$ with the $\mathrm{RC}(\mathrm{O}) \mathrm{O}_{2}$ radical fragment within the TD region. Acetate anions formed from the $\mathrm{CH}_{3} \mathrm{C}(\mathrm{O}) \mathrm{O}_{2}+\mathrm{I}^{-}$ chemistry (R6) can undergo further charge transfer resulting in spurious signals at mass-to-charge ratios corresponding to higher PANs resulting in their overestimation and a decrease in the signal for PAN itself. During HUMPPA-COPEC $\mathrm{NO}_{\mathrm{x}}$ levels were low (always less than $1 \mathrm{ppb}$, generally less than 200 pptv) and $\mathrm{NO}_{\mathrm{x}}$ related biases on our PAN measurements are negligible.

\subsubsection{Organic peroxides}

Mixing ratios of hydrogen peroxide $\left(\mathrm{H}_{2} \mathrm{O}_{2}\right)$ and total organic peroxides $(\mathrm{ROOH})$ were measured in-situ using a modified commercial instrument (Model AL2021, Aero-Laser $\mathrm{GmbH}$, Garmisch-Partenkirchen, Germany) based on the horseradish peroxidase/catalase/p-hydroxyphenyl acetic acid wet chemical fluorescence measurement technique described by (Lazrus et al., 1986). The operation of two channels allows the quantification of $\mathrm{H}_{2} \mathrm{O}_{2}$, and an estimate of total organic hydroperoxides $(\mathrm{ROOH})$ can be made assuming an average efficiency of detection (related to solubility) for the organic peroxides. For the calibration of the ICIMS sensitivity 


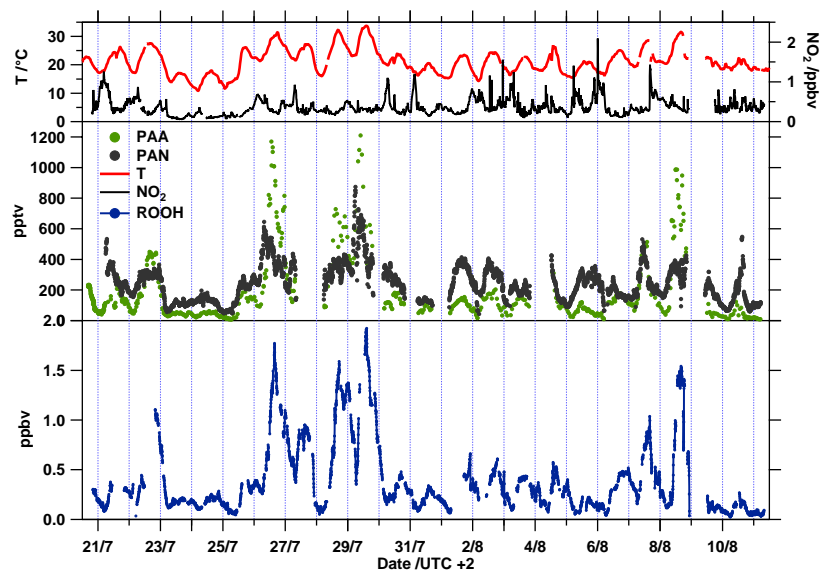

Fig. 4. Time series of PAN, and PAA and organic peroxides (ROOH) between 21 July and 12 August 2010 during the HUMPPA-COPEC experiment along with (top panel) $\mathrm{NO}_{2}$ mixing ratios and temperature.

to PAA, zero measurements and liquid calibrations of $\mathrm{H}_{2} \mathrm{O}_{2}$ were performed to quantify instrument drifts. Gas calibrations were made using a $\mathrm{H}_{2} \mathrm{O}_{2}$ permeation source to estimate the inlet efficiency for $\mathrm{H}_{2} \mathrm{O}_{2}$. A stripping efficiency for PAA was measured as $90( \pm 5) \%$ which is consistent with calculations using Henry's law.

\section{Results and discussion}

\subsection{PAN and PAA}

The time series of PAN and PAA for the HUMPPA-COPEC campaign are shown in Fig. 4. The data indicate the expected correlation between two trace-gases with a common radical source $\left(\mathrm{CH}_{3} \mathrm{C}(\mathrm{O}) \mathrm{O}_{2}\right)$ with maximum mixing ratios of about $1.2 \mathrm{ppbv}$ for PAA and $800 \mathrm{pptv}$ for PAN. Although the PAN mixing ratio usually exceeded that of PAA, on four occasions, all marked by temperatures above the campaign average (22, 26, 28-29 July and 8 August), the PAA mixing ratio was larger. Also shown in this figure is a time series of total organic peroxides, which are clearly correlated very closely with PAA, although the absolute contribution of PAA to the total organic peroxide budget is difficult to determine owing to the reliance of the total organic peroxide measurement on an assumed combination of detection efficiencies corresponding to the individual contribution of each organic peroxide to the total signal. The close correlation of the $\mathrm{ROOH}$ and CIMS PAA data is shown in a scatter plot (Fig. 5).

On some occasions, usually at nightime when relative humidity increased or during rainy or misty periods, the PAA mixing ratio was dramatically reduced due to efficient wet and/or dry deposition onto moist surfaces. This observation, typical of a soluble species, and the obvious correlation with the $\mathrm{ROOH}$ data provided early clues to help identify the

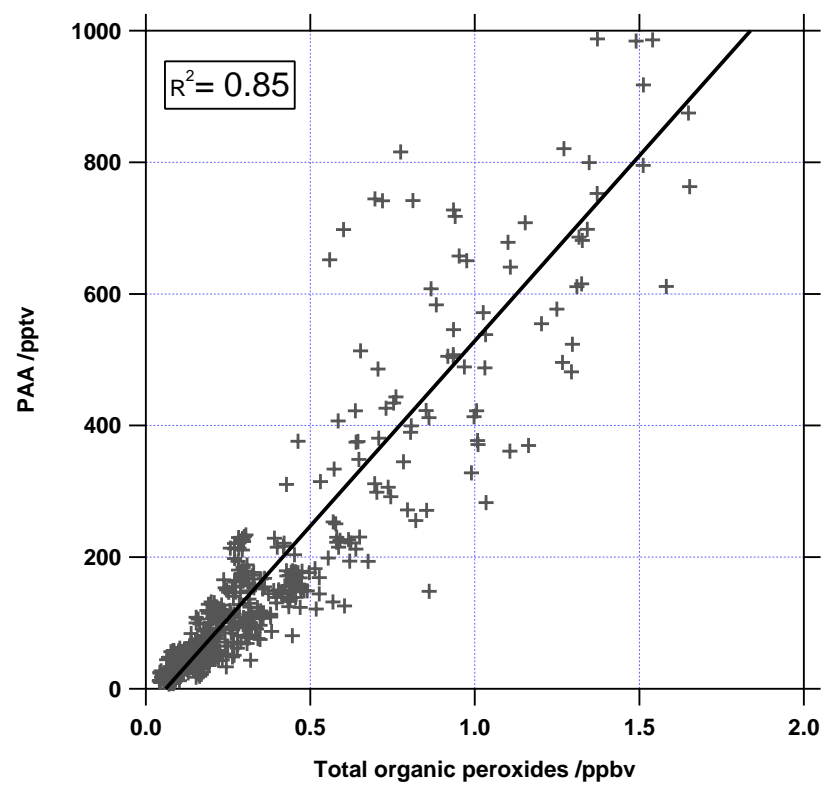

Fig. 5. Scatter plot of ICIMS PAA versus total organic peroxides for the whole campaign.

source of the signal at $m / z=59$ when operating the cold inlet.

The largest mixing ratios of both PAN and PAA were observed during the period 26-30 July, in which the highest temperatures $\left(>30^{\circ} \mathrm{C}\right)$ were recorded. At the largest temperatures encountered during the campaign, the lifetime of PAN with respect to thermal dissociation was of the order of only 20 min. Under such conditions, PAN can be considered to have been locally generated and is not being transported to the site from distant pollution sources.

Figure 6 shows the average diurnal mixing ratios of PAN and PAA for the whole campaign, as well as the temperature and the PAA-to-PAN ratio. Average mixing ratios of PAN ranged between $150 \mathrm{pptv}$ at $03: 30$ and a maximum of 300 pptv at 12:30 (times are UTC+2) with a range of approximately 100-150 pptv between the 25th and 75th percentile of the data. The average concentrations of PAA ranged between 60 pptv, at 04:30, and $280 \mathrm{pptv}$, at 13:30, with a variable range of a few tens of pptv at night to 300 pptv between the 25th and 75th percentile during the middle of the day. The average PAA diurnal profile is more modulated that that of PAN and PAA is clearly lost more rapidly at night. This observation is consistent with the relative solubility (PAA/PAN) of $>100$ (Sander, 1997) resulting in more efficient deposition to the canopy due to its radiative cooling after sunset, which promotes the condensation of atmospheric moisture.

The lowermost panel of Fig. 6 plots the average PAA-toPAN ratio, which varies between 0.4 in the early morning, at the lowest temperatures, and reaches a maximum of 1.0 in the mid-afternoon. This ratio closely tracks the average daily 


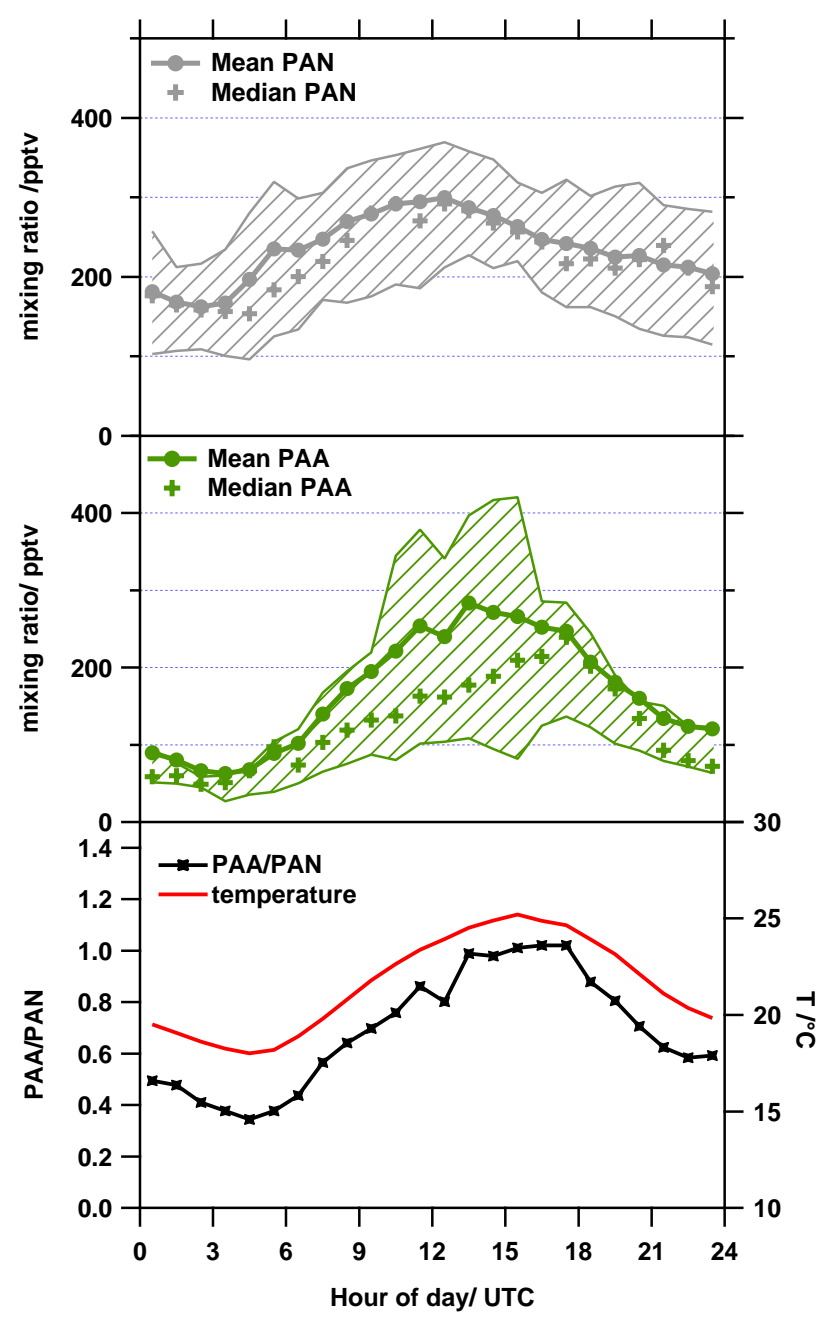

Fig. 6. Diel PAN (top panel) and PAA (middle panel) profiles during HUMPPA-COPEC-2010. The range (25-75th percentile) is indicated by the hatched area. The bottom panel shows the diel PAAto-PAN ratio alongside the diel temperature during the campaign.

variation in temperature and is largely driven by the PAN thermal decomposition rate.

This is understood when we examine the production and loss processes which determine the PAN and PAA mixing ratios. Assuming that both PAA and PAN acquire stationary state concentrations determined by the production terms in 1 and 3 and that PAN is lost by thermal decomposition (2) and deposition and PAA is lost by reaction with $\mathrm{OH}$ and deposition we can show that the PAA/PAN ratio is given by:

$\frac{\mathrm{PAA}}{\mathrm{PAN}}=\frac{\left[\mathrm{HO}_{2}\right]}{\left[\mathrm{NO}_{2}\right]} \cdot \frac{k_{4 \mathrm{a}}\left(k_{2}+D_{\mathrm{PAN}}\right)}{k_{1}\left(k_{5}[\mathrm{OH}]+D_{\mathrm{PAA}}\right)}$

where $\left[\mathrm{HO}_{2}\right]$ and $\left[\mathrm{NO}_{2}\right]$ are the concentrations of $\mathrm{HO}_{2}$ and $\mathrm{NO}_{2}, k_{i}$ are rate coefficients for reactions $R_{i}$, and $D_{\text {PAN }}$ and $D_{\text {PAA }}$ are first-order loss terms for deposition of PAN and PAA. Under the warm conditions of this campaign, the thermal deposition rate dominates over the deposition loss term

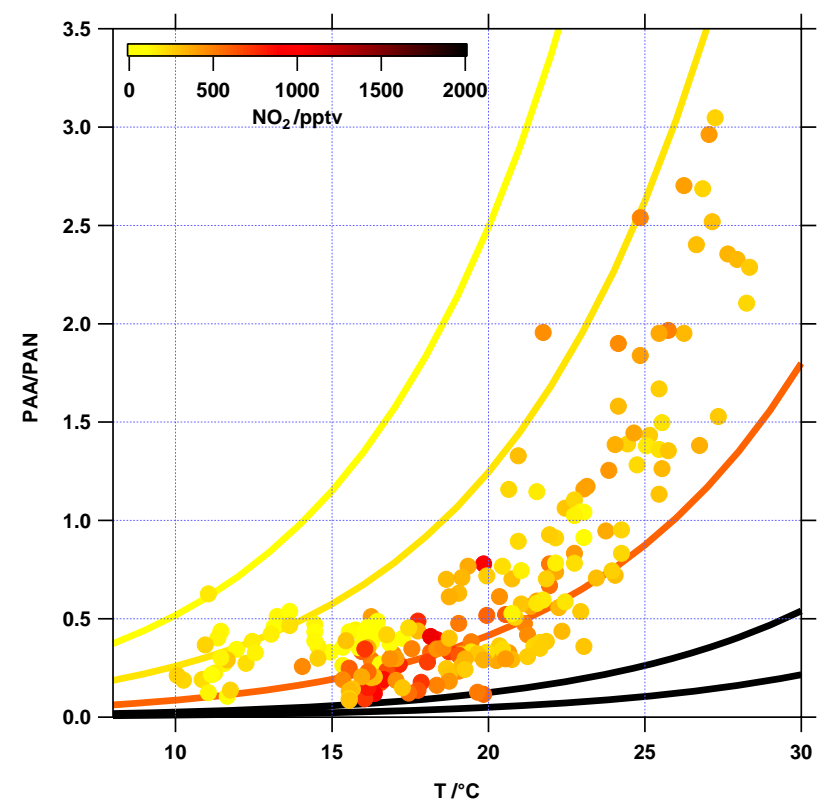

Fig. 7. The relationship between the HUMPPA-COPEC PAA/PAN ratio and temperature. The solid lines are calculations of the ratio based on expression (2) at mixing ratios of $\mathrm{NO}_{2}$ corresponding to $0.1,0.2,0.6,2$, and 5 ppbv.

for PAN and this expression simplifies to:

$\frac{\mathrm{PAA}}{\mathrm{PAN}}=\frac{\left[\mathrm{HO}_{2}\right]}{\left[\mathrm{NO}_{2}\right]} \cdot \frac{k_{4 \mathrm{a}} k_{2}}{k_{1}\left(k_{5}[\mathrm{OH}]+D_{\mathrm{PAA}}\right)}$

Values of $k_{1}$ and $k_{2}$, the PAN formation and decomposition rate coefficients, are quite well known, the latter being strongly temperature dependent with $k_{2}$ proportional to $\exp (-13000 / T)$ (Atkinson et al., 2004). Whilst kinetic data for the overall reaction $k_{4}$ are well known, the branching ratio to PAA is uncertain, $0.4 \pm 0.2$ (Atkinson et al., 2006). There are also no experimental determinations of $k_{5}$, though, as mentioned above, a rate coefficient close to $10^{-12} \mathrm{~cm}^{3}$ molecule ${ }^{-1} \mathrm{~s}^{-1}$ seems reasonable and would result in lifetimes which are comparable to those due to dry deposition (i.e. $k_{5}[\mathrm{OH}] \sim D_{\mathrm{PAA}}$ ) (Baer and Nestor, 1992). This simple equation indicates that, for a given temperature, the PAA-to-PAN ratio is determined by the $\mathrm{HO}_{2}$ to $\mathrm{NO}_{2}$ ratio.

Figure 7 displays the PAA-to-PAN ratio plotted against temperature during the hours of sunlight. The solid lines are calculations of the ratio from Eq. (2) over the campaign temperature range. Recommended kinetic parameters $\left(k_{1}, k_{2}, k_{4 \mathrm{a}}\right)$ were taken where available, $k_{5}$ was fixed independent of temperature at $3 \times 10^{-12} \mathrm{~cm}^{3}$ molecule ${ }^{-1} \mathrm{~s}^{-1}$. The $\mathrm{HO}_{2}$ mixing ratio (30 pptv), $\mathrm{OH}$ concentration $\left(2 \times 10^{6}\right.$ molecules $\left.\mathrm{cm}^{-3}\right)$ and the PAA deposition rate $\left(D_{\mathrm{PAA}}=\right.$ $5 \times 10^{-6} \mathrm{~s}^{-1}$ corresponding to a deposition velocity of $0.5 \mathrm{~cm} \mathrm{~s}^{-1}$ in a $1 \mathrm{~km}$ high BL) were adjusted as representative of the dataset. Hens et al. (2013) will report concentrations of 


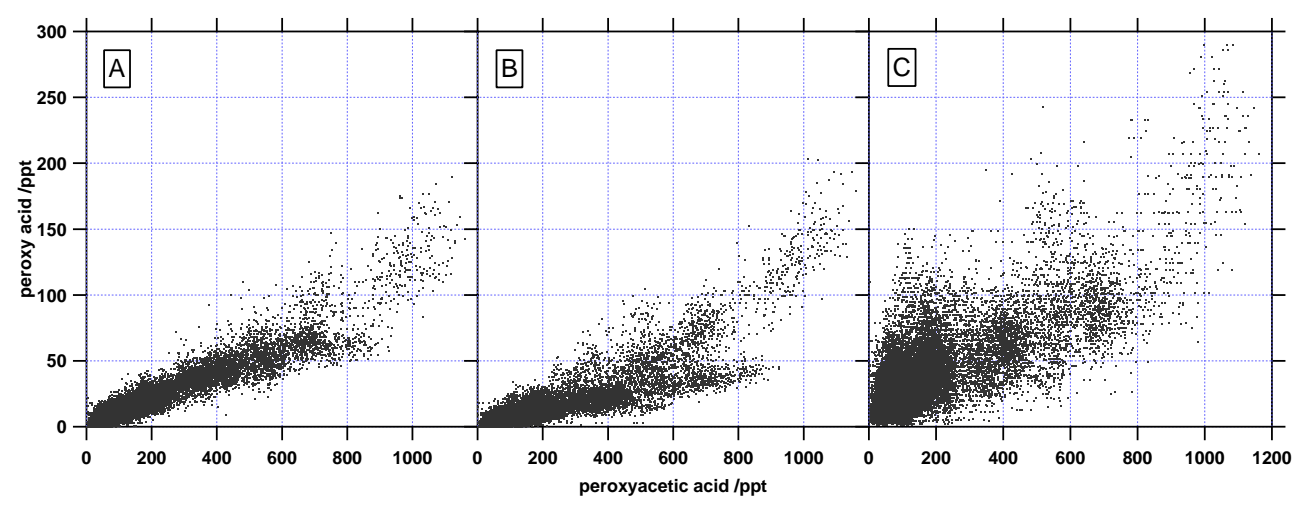

Fig. 8. Relationship between (A) PPA vs. PAA, (B) PBA vs. PAA, and (C) MPA vs. PAA for all data during HUMPPA-COPEC assuming the same PAA-equivalent instrument sensitivity for all acids.

$\mathrm{HO}_{\mathrm{x}}$ for this campaign and 30 pptv $\mathrm{HO}_{2}$ is not an unreasonable estimate. Note the non-linear response of the PAA/PAN ratio with temperature (driven by the exponential dependence of $k_{2}$ on temperature) and the weaker dependence on $\mathrm{NO}_{\mathrm{x}}$ variations is semi-quantitatively captured by this simple calculation.

While it is evident that the assumptions within the steadystate approximation are not strictly valid, and that a single, time invariant value for the $\mathrm{HO}_{2}$ mixing ratio and the deposition velocity of PAA are simplifying estimates, the relationship between PAA and PAN in the conditions encountered during HUMPPA-COPEC, namely low $\mathrm{NO}_{\mathrm{x}}$ and high temperatures, give us a valuable insight into the relative importance of $\mathrm{HO}_{2}$ and $\mathrm{NO}_{\mathrm{x}}$ in the dataset and can, to some extent at least, allow one to place a boundary on the $\mathrm{HO}_{2}$ present at the site. This aspect of the PAA/PAN measurements will be examined in a later publication in a more rigorous examination of the photochemistry of this site, including comparison to measured radical concentrations.

Three other peroxyacyl nitrate-peroxy acid pairs were monitored during HUMPPA-COPEC. Mass-to-charge ratios 73, 85 and 87, corresponding to PPN, MPAN and PBN, were all measured and found to have significant interferences from their corresponding acid. Figure 8 shows the relationship between PAA and each of three other peracids assuming the same instrument sensitivity as for PAA. The campaign average contribution and range (25th and 75 th percentiles), in units of raw signal, of the peracid signal to the total signal (acylperoxynitrate + peroxy acid) for each $\mathrm{m} / z$ was $31 \%$ (21-47) for $m / z=73,76 \%$ (58-100) for $m / z=85$, and $59 \%(41-80)$ for $m / z=87$.

\subsection{Implications for the measurement of speciated PAN fluxes by eddy covariance}

The detection of peracids as a significant proportion of the signal measured at the carboxylate mass-to-charge ratios using iodide CIMS has implications for PAN measurements using TD-ICIMS. Not all instruments are necessarily equally sensitive to PAA; however, these measurements raise an important issue when attempting to measure PANs with TDICIMS in environments in which peracids may be reasonably expected.

When measuring PAN concentrations it is possible to avoid artefacts from PAA by either using the addition of NO for the analytical zero, or by measuring the zero without a heated TD region. The addition of NO removes the PA radical formed within the TD region but does not remove PAA and thus signal due to PAA is removed by subtraction. With no heated region, PAN does not dissociate leaving only PAA available for detection. The effectiveness of either of the above methods of correction depends on the variability of PAA, the frequency of the zero, and the relative contribution of PAA to the acetate ion signal.

The correction of flux measurements by eddy covariance is more problematic. The turbulent flux of scalar components can be measured as the covariance between the concentration of the scalar and the vertical wind component, which in practice is achieved via rapid measurements of vertical wind velocity and the concentration scalar (Kaimal and Finnegan, 1994). If the variability of the scalar is dependent on an artefact in addition to the variable of interest, the flux must be corrected by the flux of the artefact and cannot be removed by the zeroing methods described above. For the specific case of PAN and PAA, it is likely that PAA would exhibit larger deposition velocities than PAN owing to its much greater solubility and relatively high reactivity (e.g. Baer et al., 1992). It is likely therefore that variability detected in the acetate ion using TD-ICIMS will have a significant contribution from PAA and therefore require correction before the promulgation of PAN fluxes.

A number of studies have reported fluxes of PAN using Eddy correlation and the ICIMS technique (Turnipseed et al., 2006; Wolfe et al., 2009; Min et al., 2012). Turnipseed et al. (2006), in a study of PAN fluxes above loblolly pine, found that their measured deposition velocities were larger than were predicted by models and that PAN deposition 
velocities were increased in wet conditions, consistent with possible contamination of the PAN flux by PAA sensitivity. The data in Turnipseed et al. (2006) have been used to assess the ability of two community models (WRF-Chem dry deposition module [WDDM] and NOAA-gas exchange model [NOAA-GEM]) to simulate the dry deposition velocities of PAN (Wu et al., 2012). The authors found that both models underestimate the measured deposition velocities, by a factor of 5 for WDDM and 1.6 for NOAA-GEM. The discrepancy between the simulation results and the measurements reached a maximum during wet periods.

In measurements above Pinus ponderosa L. at Blodgett forest, Wolfe et al. (2009) measured PAN fluxes via eddy correlation using TD-ICIMS during BEARPEX 2007. In response to the discussion version of this paper (http://www.atmos-chem-phys-discuss.net/12/20181/ 2012/acpd-12-20181-2012.pdf) J. Thornton provided an assessment of a possible PAA artefact during BEARPEX 2007 (http://www.atmos-chem-phys-discuss.net/12/C7744/ 2012/acpd-12-C7744-2012.pdf). The background in the BEARPEX 2007 dataset was determined using NO additions and as noted earlier in Sect. 2 this method does not remove PAA and thus PAA will contribute signal to background and not to the PAN signal. A comparison of the ICIMS background signal with simultaneous unpublished measurements of PAA using a $\mathrm{CF}_{3} \mathrm{O}^{-}$CIMS method (Crounse et al., 2006) shows good agreement $\left(r^{2}=0.71\right)$ suggesting that the ICIMS was sensitive to PAA during BEARPEX 2007 with a sensitivity 10 times less than that for PAN. J. Thornton also provides an estimation of the effect of detecting PAA on the estimation of PAN fluxes and concludes that PAA may have been measured as an upper-limit PAN-equivalent flux of approximately $-0.1 \mathrm{ppt} \mathrm{ms}^{-1}$ on average during the day up to a maximum of $-0.3 \mathrm{ppt} \mathrm{ms}^{-1}$ on an average daytime PAN flux of $-1.5 \mathrm{ppt} \mathrm{ms}{ }^{-1}$. Wolfe et al. (2009) do not report PAN deposition velocities during wet conditions owing to the malfunctioning of the sonic anemometer and so any inference of a soluble component of the flux was not possible.

Min et al. (2012), also measuring in Blodgett forest (BEARPEX 2009), present a comparison of $\Sigma$ PN fluxes by EC-TD-LIF (Farmer et al., 2006) with measurements of speciated peroxynitrates fluxes by EC-TD-CIMS. A discrepancy was observed between the two techniques, proposed to be due to the formation of peroxynitrates other than ones measured by the CIMS in the study. The ICIMS determination of the flux of the sum of speciated PAN fluxes being 30-60\% more negative than the flux of $\Sigma$ PN determined with TD-LIF. Min et al. (2012) also responded to the discussion version of this paper in the final version of their paper and attempted to address the potential PAA artefact on the measure of PAN fluxes. They include a plot of the diurnal average of the NOaddition generated background signal and show a average diurnal cycle with a peak of 50 pptv PAN equivalent which is qualitively similar to the one reported in this paper observed in the afternoon indicating that the BEARPEX 2009 ICIMS was sensitive to PAA. Min et al. (2012) estimate that PAA could be responsible for 10-40\% of the discrepancy between the different methods of estimating fluxes of PANs although they note that the PAN-equivalent data exhibits the opposite vertical gradient one would expect for a species with a faster deposition velocity. It is also possible that the tentative evidence that we obtained for peracid analogous to MPAN and PPN could be responsible for an addition small part of this discrepancy.

It is however difficult to assess the particular consequences of the detection of PAA fluxes as an artefact of the determination of PAN fluxes in each case owing to the complex interaction of in-canopy chemistry, unknown ambient fluxes of PAA, combined with unknown or highly uncertain instrument PAA sensitivities. In addition to PAN itself, the measurement of inferences at the masses commonly used to monitor PPN, PBN, and MPAN suggest that a similar issue might arise for the fluxes of these components. Again, the real effect of these interferants will depend on the precise ICIMS operating conditions and environmental variables of particular studies. Analyses using PAN-equivalent concentrations do not take into account the likely instrument dependent characteristics of PAA sensitivities such as humidity dependencies which could alter and even reverse trends observed in raw data.

\section{Conclusions}

We present measurements of PAN and PAA using ICIMS by monitoring the acetate ion $(m / z=59)$ signal using an alternating heated and ambient temperature inlet system. Concentrations of PAA and PAN were, on average, very similar varying between 100 to $300 \mathrm{pptv}$, with the ratio of PAA-toPAN varying, on average, between 0.4 early in the morning up to 1.0 in the mid-afternoon. The PAA-to-PAN ratio is controlled strongly by temperature in these low $\mathrm{NO}_{\mathrm{x}}$ conditions and analysis of the steady-state relationship of the two compounds allows, with some assumptions, determination of the relationship between $\mathrm{NO}_{2}$ and $\mathrm{HO}_{2}$. PAA is a large proportion of the total signal at $m / z=59$, in our system, and interferes with measurements of PAN unless corrected, in the case of concentration measurements, by frequent instrument zeros by NO addition or inlet heater cycling. For ICIMS operated under conditions whereby sufficient sensitivity to PAA is (intentionally or otherwise) available, correction of fluxes measured via the eddy covariance technique is more complex and the flux of PAA will need to be determined separately to correct the flux of PAN. It cannot be completely excluded, that previously published deposition velocities of PAN by TD-ICIMS are enhanced by PAA measured as an artefact. It is important that users of the ICIMS technique for PANs measurements determine the instrument sensitivity to PAA to either utilise the capability of detection or to account for its appearance as an artefact. 
Acknowledgements. The authors are grateful for the support of the Hyytiälä site engineers and staff. Support of the European Community - Research Infrastructure Action under the FP6 "Structuring the European Research Area" Programme, EUSAAR Contract No. RII3-CT-2006-026140 is gratefully acknowledged.

The service charges for this open access publication have been covered by the Max Planck Society.

Edited by: A. Goldstein

\section{References}

Atkinson, R. and Arey, J.: Gas-phase tropospheric chemistry of biogenic volatile organic compounds: A review, Atmos. Environ., 37, S197-S219, 2003.

Atkinson, R., Baulch, D. L., Cox, R. A., Crowley, J. N., Hampson, R. F., Hynes, R. G., Jenkin, M. E., Rossi, M. J., and Troe, J.: Evaluated kinetic and photochemical data for atmospheric chemistry: Volume $\mathrm{I}$ - gas phase reactions of $\mathrm{O}_{\mathrm{x}}, \mathrm{HO}_{\mathrm{x}}, \mathrm{NO}_{\mathrm{x}}$ and $\mathrm{SO}_{\mathrm{x}}$ species, Atmos. Chem. Phys., 4, 1461-1738, doi:10.5194/acp-41461-2004, 2004.

Atkinson, R., Baulch, D. L., Cox, R. A., Crowley, J. N., Hampson, R. F., Hynes, R. G., Jenkin, M. E., Rossi, M. J., Troe, J., and IUPAC Subcommittee: Evaluated kinetic and photochemical data for atmospheric chemistry: Volume II - gas phase reactions of organic species, Atmos. Chem. Phys., 6, 3625-4055, doi:10.5194/acp-6-3625-2006, 2006.

Baer, M. and Nester, K.: Parametrization of trace gas dry deposition velocities for a regional mesoscale diffusion-model, Ann. Geophys.-Atmos. Hydrospheres Space Sci., 10, 912-923, 1992.

Crounse, J. D., McKinney, K. A., Kwan, A. J., and Wennberg, P. O.: Measurement of gas-phase hydroperoxides by chemical ionization mass spectrometry, Anal. Chem., 78, 6726-6732, 2006.

Dillon, T. J. and Crowley, J. N.: Direct detection of OH formation in the reactions of $\mathrm{HO}_{2}$ with $\mathrm{CH}_{3} \mathrm{C}(\mathrm{O}) \mathrm{O}_{2}$ and other substituted peroxy radicals, Atmos. Chem. Phys., 8, 4877-4889, doi:10.5194/acp-8-4877-2008, 2008.

Fantechi, G., Vereecken, L., and Peeters, J.: The OH-initiated atmospheric oxidation of pinonaldehyde: Detailed theoretical study and mechanism construction, Phys. Chem. Chem. Phys., 4, 5795-5805, doi:10.1039/b205901k, 2002.

Farmer, D. K., Wooldridge, P. J., and Cohen, R. C.: Application of thermal-dissociation laser induced fluorescence (TD-LIF) to measurement of $\mathrm{HNO}_{3}$, Salkyl nitrates, Speroxy nitrates, and $\mathrm{NO}_{2}$ fluxes using eddy covariance, Atmos. Chem. Phys., 6, 3471-3486, doi:10.5194/acp-6-3471-2006, 2006.

Fels, M. and Junkermann, W.: The occurrence of organic peroxides in air at a mountain site, Geophys. Res. Lett., 21, 341-344, doi:10.1029/93gl01892, 1994.

Fischer, E. V., Jaffe, D. A., and Weatherhead, E. C.: Free tropospheric peroxyacetyl nitrate (PAN) and ozone at Mount Bachelor: potential causes of variability and timescale for trend detection, Atmos. Chem. Phys., 11, 5641-5654, doi:10.5194/acp-115641-2011, 2011.

Furgeson, A., Mielke, L. H., Paul, D., and Osthoff, H. D.: A photochemical source of peroxypropionic and peroxyisobutanoic nitric anhydride, Atmos. Environ., 45, 5025-5032, doi:10.1016/j.atmosenv.2011.03.072, 2011.
Hastie, D. R., Gray, J., Langford, V. S., Maclagan, R. G. A. R., Milligan, D. B., and McEwan, M. J.: Real-time measurement of peroxyacetyl nitrate using selected ion flow tube mass spectrometry, Rapid Commun. Mass Spectrom., 24, 343-348, doi:10.1002/rcm.4400, 2010.

He, S. Z., Chen, Z. M., Zhang, X., Zhao, Y., Huang, D. M., Zhao, J. N., Zhu, T., Hu, M., and Zeng, L. M.: Measurement of atmospheric hydrogen peroxide and organic peroxides in Beijing before and during the 2008 Olympic games: Chemical and physical factors influencing their concentrations, J. Geophys. Res.Atmos., 115, D17307 doi:10.1029/2009jd013544, 2010.

Hens, K., Novelli, A., Auld, J., Axinte, R., Bohn, B., Crowley, J., Fischer, H., Gonzalez Orozco, D., Hosaynali Beygi, Z., Keronen, P., Klüpfel, T., Königstedt, R., Kubistin, D., Martinez, M., Mesarchaki, E., Nölscher, A., Oswald, R., Paasonen, P., Petäjä, T., Rudolf, M., Sander, R., Sipilä, M., Song, W., Taraborrelli, D., Trawny, K., Valverde Canossa, J., Williams, J., Lelieveld, J., and Harder, H.: Observation and modelling of the hydroxyl radical during HUMPPA-COPEC 2010, Atmos. Chem. Phys. Discuss., in preparation, 2013.

Kaimal, J. C. and Finnegan, J. J.: Atmospheric boundary layer flows, Oxford University Press, 1994.

LaFranchi, B. W., Wolfe, G. M., Thornton, J. A., Harrold, S. A., Browne, E. C., Min, K. E., Wooldridge, P. J., Gilman, J. B., Kuster, W. C., Goldan, P. D., de Gouw, J. A., McKay, M., Goldstein, A. H., Ren, X., Mao, J., and Cohen, R. C.: Closing the peroxy acetyl nitrate budget: observations of acyl peroxy nitrates (PAN, PPN, and MPAN) during BEARPEX 2007, Atmos. Chem. Phys., 9, 7623-7641, doi:10.5194/acp-9-7623-2009, 2009.

Lazrus, A. L., Kok, G. L., Lind, J. A., Gitlin, S. N., Heikes, B. G., and Shetter, R. E.: Automated fluorometric method for hydrogen-peroxide in air, Anal. Chem., 58, 594-597, doi:10.1021/ac00294a024, 1986.

Mielke, L. H. and Osthoff, H. D.: On quantitative measurements of peroxycarboxylic nitric anhydride mixing ratios by thermal dissociation chemical ionization mass spectrometry, Int. J. Mass Spectrom., 310, 1-9, doi:10.1016/j.ijms.2011.10.005, 2012.

Min, K.-E., Pusede, S. E., Browne, E. C., LaFranchi, B. W., Wooldridge, P. J., Wolfe, G. M., Harrold, S. A., Thornton, J. A., and Cohen, R. C.: Observations of atmosphere-biosphere exchange of total and speciated peroxynitrates: nitrogen fluxes and biogenic sources of peroxynitrates, Atmos. Chem. Phys., 12, 9763-9773, doi:10.5194/acp-12-9763-2012, 2012.

Orlando, J. J. and Tyndall, G. S.: Gas phase UV absorption spectra for peracetic acid, and for acetic acid monomers and dimers, J. Photochem. Photobiol. A-Chem., 157, 161-166, 2003.

Peeters, J., Vereecken, L., and Fantechi, G.: The detailed mechanism of the $\mathrm{OH}$-initiated atmospheric oxidation of $\alpha$-pinene: A theoretical study, PCCP, 3, 5489-5504, 2001.

Roberts, J. M., Williams, J., Baumann, K., Buhr, M. P., Goldan, P. D., Holloway, J., Hubler, G., Kuster, W. C., McKeen, S. A., Ryerson, T. B., Trainer, M., Williams, E. J., Fehsenfeld, F. C., Bertman, S. B., Nouaime, G., Seaver, C., Grodzinsky, G., Rodgers, M., and Young, V. L.: Measurements of PAN, PPN, and MPAN made during the 1994 and 1995 Nashville intensives of the southern oxidant study: Implications for regional ozone production from biogenic hydrocarbons, J. Geophys. Res.-Atmos., 103, 22473-22490, doi:10.1029/98jd01637, 1998. 
Roberts, J. M., Jobson, B. T., Kuster, W., Goldan, P., Murphy, P., Williams, E., Frost, G., Riemer, D., Apel, E., Stroud, C., Wiedinmyer, C., and Fehsenfeld, F.: An examination of the chemistry of peroxycarboxylic nitric anhydrides and related volatile organic compounds during Texas air quality study 2000 using ground-based measurements, J. Geophys. Res., 108, 4495, doi:10.1029/2003jd003383, 2003.

Roberts, J. M., Marchewka, M., Bertman, S. B., Sommariva, R., Warneke, C., de Gouw, J., Kuster, W., Goldan, P., Williams, E., Lerner, B. M., Murphy, P., and Fehsenfeld, F. C.: Measurements of PANs during the New England air quality study 2002, J. Geophys. Res.-Atmos., 112, D20306, doi:10.1029/2007jd008667, 2007.

Roiger, A., Aufmhoff, H., Stock, P., Arnold, F., and Schlager, H.: An aircraft-borne chemical ionization - ion trap mass spectrometer (CI-ITMS) for fast PAN and PPN measurements, Atmos. Meas. Tech., 4, 173-188, doi:10.5194/amt-4-173-2011, 2011.

Sander, R.: Compilation of Henry's Law Constants for Inorganic and Organic Species of Potential Importance in Environmental Chemistry (Version 3), available at: http://www.henrys-law.org, 1999.

Singh, H. B. and Hanst, P. L.: Peroxyacetyl nitrate (PAN) in the unpolluted atmosphere - an important reservoir for nitrogen-oxides, Geophys. Res. Lett., 8, 941-944, doi:10.1029/GL008i008p00941, 1981.

Singh, H. B. and Salas, L. J.: Peroxyacetyl nitrate in the free troposphere, Nature, 302, 326-328, doi:10.1038/302326a0, 1983.

Singh, H. B., Ohara, D., Herlth, D., Bradshaw, J. D., Sandholm, S. T., Gregory, G. L., Sachse, G. W., Blake, D. R., Crutzen, P. J., and Kanakidou, M. A.: Atmospheric measurements of peroxyacetyl nitrate and other organic nitrates at high-latitudes possible sources and sinks, J. Geophys. Res.-Atmos., 97, 1651116522, 1992.

Slusher, D. L., Huey, L. G., Tanner, D. J., Flocke, F. M., and Roberts, J. M.: A thermal dissociation-chemical ionization mass spectrometry (TD-CIMS) technique for the simultaneous measurement of peroxyacyl nitrates and dinitrogen pentoxide, J. Geophys. Res.-Atmos., 109, D19315, doi:10.1029/2004JD004670, 2004.

Sparks, J. P., Roberts, J. M., and Monson, R. K.: The uptake of gaseous organic nitrogen by leaves: A significant global nitrogen transfer process, Geophys. Res. Lett., 30, 2189, doi:10.1029/2003g1018578, 2003.

Stephens, E. R., Darley, E. F., Taylor, O. C., and Scott, W. E.: Photochemical-reaction products in air-pollution, Int. J. Air Water Pollut., 4, 79-100, 1961.

Talukdar, R. K., Burkholder, J. B., Schmoltner, A. M., Roberts, J. M., Wilson, R. R., and Ravishankara, A. R.: Investigation of the loss processes for peroxyacetyl nitrate in the atmosphere-UV photolysis and reaction with $\mathrm{OH}, \mathrm{J}$. Geophys. Res.-Atmos., 100, 14163-14173, doi:10.1029/95jd00545, 1995.

Taraborrelli, D., Lawrence, M. G., Crowley, J. N., Dillon, T. J., Gromov, S., Groß, C., Vereecken, L., and Lelieveld, J.: Hydroxyl radical buffered by isoprene oxidation over tropical forests, Nature Geosci., 5, 190-193, 2012.

Turnipseed, A. A., Huey, L. G., Nemitz, E., Stickel, R., Higgs, J., Tanner, D. J., Slusher, D. L., Sparks, J. P., Flocke, F., and Guenther, A.: Eddy covariance fluxes of peroxyacetyl nitrates (PANs) and $\mathrm{NO}_{\mathrm{y}}$ to a coniferous forest, J. Geophys. Res.-Atmos., 111,
D09304, doi:10.1029/2005jd006631, 2006.

Warneck, P. and Zerbach, T.: Synthesis of peroxyacetyl nitrate in air by acetone photolysis, Environ. Sci. Technol., 26, 74-79, doi:10.1021/es00025a005, 1992.

Williams, J., Crowley, J., Fischer, H., Harder, H., Martinez, M., Petäjä, T., Rinne, J., Bäck, J., Boy, M., Dal Maso, M., Hakala, J., Kajos, M., Keronen, P., Rantala, P., Aalto, J., Aaltonen, H., Paatero, J., Vesala, T., Hakola, H., Levula, J., Pohja, T., Herrmann, F., Auld, J., Mesarchaki, E., Song, W., Yassaa, N., Nölscher, A., Johnson, A. M., Custer, T., Sinha, V., Thieser, J., Pouvesle, N., Taraborrelli, D., Tang, M. J., Bozem, H., Hosaynali-Beygi, Z., Axinte, R., Oswald, R., Novelli, A., Kubistin, D., Hens, K., Javed, U., Trawny, K., Breitenberger, C., Hidalgo, P. J., Ebben, C. J., Geiger, F. M., Corrigan, A. L., Russell, L. M., Ouwersloot, H. G., Vilà-Guerau de Arellano, J., Ganzeveld, L., Vogel, A., Beck, M., Bayerle, A., Kampf, C. J., Bertelmann, M., Köllner, F., Hoffmann, T., Valverde, J., González, D., Riekkola, M.-L., Kulmala, M., and Lelieveld, J.: The summertime Boreal forest field measurement intensive (HUMPPA-COPEC-2010): an overview of meteorological and chemical influences, Atmos. Chem. Phys., 11, 10599-10618, doi:10.5194/acp-11-10599-2011, 2011.

Wolfe, G. M., Thornton, J. A., McNeill, V. F., Jaffe, D. A., Reidmiller, D., Chand, D., Smith, J., Swartzendruber, P., Flocke, F., and Zheng, W.: Influence of trans-Pacific pollution transport on acyl peroxy nitrate abundances and speciation at Mount Bachelor Observatory during INTEX-B, Atmos. Chem. Phys., 7, 53095325, doi:10.5194/acp-7-5309-2007, 2007.

Wolfe, G. M., Thornton, J. A., Yatavelli, R. L. N., McKay, M., Goldstein, A. H., LaFranchi, B., Min, K.-E., and Cohen, R. C.: Eddy covariance fluxes of acyl peroxy nitrates (PAN, PPN and MPAN) above a Ponderosa pine forest, Atmos. Chem. Phys., 9, 615-634, doi:10.5194/acp-9-615-2009, 2009.

Wooldridge, P. J., Perring, A. E., Bertram, T. H., Flocke, F. M., Roberts, J. M., Singh, H. B., Huey, L. G., Thornton, J. A., Wolfe, G. M., Murphy, J. G., Fry, J. L., Rollins, A. W., LaFranchi, B. W., and Cohen, R. C.: Total Peroxy Nitrates (SPNs) in the atmosphere: the Thermal Dissociation-Laser Induced Fluorescence (TD-LIF) technique and comparisons to speciated PAN measurements, Atmos. Meas. Tech., 3, 593-607, doi:10.5194/amt-3-5932010, 2010.

Wu, Z., Wang, X., Turnipseed, A. A., Chen, F., Zhang, L., Guenther, A. B., Karl, T., Huey, L. G., Niyogi, D., Xia, B., and Alapaty, K.: Evaluation and improvements of two community models in simulating dry deposition velocities for peroxyacetyl nitrate (PAN) over a coniferous forest, J. Geophys. Res., 117, D04310, doi:10.1029/2011jd016751, 2012.

Zhang, X., Chen, Z. M., He, S. Z., Hua, W., Zhao, Y., and Li, J. L.: Peroxyacetic acid in urban and rural atmosphere: concentration, feedback on PAN-NO ${ }_{\mathrm{x}}$ cycle and implication on radical chemistry, Atmos. Chem. Phys., 10, 737-748, doi:10.5194/acp10-737-2010, 2010.

Zheng, W., Flocke, F. M., Tyndall, G. S., Swanson, A., Orlando, J. J., Roberts, J. M., Huey, L. G., and Tanner, D. J.: Characterization of a thermal decomposition chemical ionization mass spectrometer for the measurement of peroxy acyl nitrates (PANs) in the atmosphere, Atmos. Chem. Phys., 11, 6529-6547, doi:10.5194/acp-11-6529-2011, 2011. 